\title{
Glucagon-like peptides 1 and 2 and vasoactive intestinal peptide are neuroprotective on cultured and mast cell co-cultured rat myenteric neurons
}

\author{
Ulrikke Voss' ${ }^{1}$ Elin Sand ${ }^{1}$, Per M Hellström² ${ }^{2}$ and Eva Ekblad ${ }^{1 *}$
}

\begin{abstract}
Background: Neuropathy is believed to be a common feature of functional and inflammatory intestinal diseases. Vasoactive intestinal peptide (VIP) is an acknowledged neuroprotective agent in peripheral, including enteric, and central neurons. The proglucagon-like hormones glucagon-like peptide 1 and 2 (GLP1 and GLP2) belong to the secretin/glucagon/VIP superfamily of peptides and GLP1 and GLP2 receptors are expressed in enteric neurons. Possible neuroprotective effects of these peptides were investigated in the present study.
\end{abstract}

Methods: GLP1, GLP2 and VIP were added to cultured myenteric neurons from rat small intestine or to co-cultures of myenteric neurons and rat peritoneal mast cells. Receptor selectivity was tested by the simultaneous presence of a GLP1 receptor antagonist (exendin (9-39) amide) or a VIP receptor antagonist (hybrid of neurotensin 6-11 and VIP 7-28). Neuronal survival was examined using immunocytochemistry and cell counting.

Results: GLP1, GLP2 and VIP significantly and concentration-dependently enhanced neuronal survival. In addition the peptides efficiently counteracted mast cell-induced neuronal cell death in a concentration-dependent manner. Exendin(9-39)amide reversed GLP1-induced neuroprotection while GLP2- and VIP-induced enhanced neuronal survival were unaffected. The VIP receptor antagonist reversed GLP1- and VIP-induced neuroprotection while the GLP2-induced effect on neuronal survival was unaffected.

Conclusions: By activating separate receptors VIP, GLP1 and GLP2 elicit neuroprotective effects on rat myenteric neurons cultured with or without mast cells. This implies a powerful therapeutic potential of these peptides in enteric neuropathies with a broad spectrum of applications from autoimmunity to functional disorders.

\section{Background}

The enteric nervous system (ENS) is pivotal in the regulation and coordination of gastrointestinal (GI) motility, secretion and blood flow. GI discomfort such as nausea, bloating, abdominal pain, constipation, diarrhea or delayed gastric emptying are common features in functional bowel diseases affecting, in particular, a large number of diabetic patients [1]. The pathogenesis of GI symptoms in diabetes is not fully understood but autonomic neuropathy and abnormal glucose levels are

\footnotetext{
* Correspondence: eva.ekblad@med.lu.se

'Department of Experimental Medical Science, BMC B11, Lund University, SE22184 Lund, Sweden

Full list of author information is available at the end of the article
}

suggested to be important. In diabetic rats neurodegeneration [2] and apoptosis [3] occur in myenteric neurons. Oxidative stress is considered the most important factor in causing diabetes-induced enteric neuropathy $[4,5]$. Collectively these studies indicate the occurrence of diabetes-related neurodegenerative processes in the ENS that eventually lead to neuropathy, intestinal dysfunction and GI discomfort.

Glucagon-like peptide 1 (GLP1) attracts much attention due to its effects on glucose-stimulated insulin secretion, beta-cell proliferation and food intake. It is currently in clinical use in patients with type II diabetes in order to treat hyperglycemia and a number of beneficial side effects e.g. weight loss due to better satiety

\section{C) Biomed Central}


control [for a recent review see [6]] and protection of beta-cells against cytokine-mediated apoptosis [7] have been recognized. A number of observations also indicate that GLP1 is neuroprotective in the central nervous system [8] and clinical trials on patients with Parkinsons disease are announced [9]. In the peripheral nervous system GLP1 prevents experimentally induced sensory neuropathy $[10,11]$. In this context it is of interest to note that GLP1 given to patients with irritable bowel syndrome provides an effective, on demand, relief of acute pain attacks [12].

The incretin GLP1 is encoded within the proglucagon precursor and released, together with glucagonlike peptide 2 (GLP2) in a 1:1 ratio, from L-cells in the ileum and colon in response to food ingestion. GLP2 acts as an intestinotrophic factor mainly by stimulating crypt cell proliferation but it also possesses anti-apoptotic effects and enhances nutrient absorption. Protective effects of GLP2 have been explored in clinical entities like short bowel syndrome, total parenteral nutrition-induced intestinal atrophy and in inflammatory bowel disease (IBD) [for a review see [13]]. In trinitrobenzene sulfonic acid or dextran sodium sulfate models of IBD GLP2 treatment reduces the intestinal inflammation and counteracts inflammation-induced loss of enteric neurons. In addition, GLP2 treatment increases the number of vasoactive intestinal peptide (VIP)-expressing enteric neurons and the possibility that GLP2 effects are mediated via release of VIP is suggested [14,15]. VIP exhibits established neuroprotective properties in peripheral, including enteric, and central neurons [16-20].

Aims of the present study were to investigate possible neuroprotective effects of GLP1, GLP2 and VIP on myenteric neurons from adult rat small intestine. Two different in vitro models were used. First the ability of the three peptides to enhance neuronal survival was tested on myenteric neurons in primary culture. Next neuroprotective effects of the peptides were tested in an in vitro system in which enhanced neuronal cell death was generated by co-culturing myenteric neurons with mast cells. Receptor selectivity was, in both these models, tested by using a GLP1 receptor antagonist (exendin (9-39)amide) and a VIP receptor antagonist (hybrid neurotensin 6-11 and VIP 7-28; hybVIP).

GLP1, GLP2 and VIP were in the present study found to efficiently protect myenteric neurons in two different culture systems. Separate receptors, suggested to be neuronally expressed, were activated. These results strongly point towards a powerful therapeutic promise for these three peptides in the prevention of enteric neuropathy in diseases like diabetes, but also in inflammatory and neurodegenerative diseases.

\section{Methods}

\section{Animals}

Female Sprague-Dawley rats $(\mathrm{n}=38,170-180 \mathrm{~g})$, purchased from Charles River, Sulzfeld, Germany, were used. The rats were allowed to acclimatize to the climate- and light-controlled animal facility for at least 5 days prior execution. Standard rat chow and water were supplied at all times. The experimental design was approved by the animal ethics committee, Lund and Malmö, Sweden. Animals were used in accordance with the European Communities Council Directive (86/609/ EEC and 2010/63/EU) and the Swedish Animal Welfare Act (SFS 1988:534).

\section{Myenteric neuronal cultures}

Primary cultures of myenteric neurons were prepared from rat small intestine using a previously described method [21]. In brief, rats were deeply anaesthetized using chloral hydrate $(300 \mathrm{mg} / \mathrm{kg}$ body weight) and the small intestine was exposed via a midline incision. The longitudinal muscle with attached myenteric ganglia were stripped from approximately $20 \mathrm{~cm}$ of the distal small intestine. Stripping was performed aseptically without penetrating the gut thereby avoiding contamination by luminal fecal matter. The tissue was cut into smaller pieces $(2 \times 2 \mathrm{~mm})$ and washed in $\mathrm{Ca}^{2+}$ - and $\mathrm{Mg}^{2+}$ - free Hank's balanced salt solution (HBSS, Gibco, BRL, Life Technologies AB, Stockholm, Sweden). Tissues were placed in HBSS containing collagenase II (1.5 $\mathrm{mg} / \mathrm{ml}$, Life Technologies $\mathrm{AB})$ and protease $(1.5 \mathrm{mg} / \mathrm{ml}$, Sigma-Aldrich, Stockholm, Sweden) and mechanically separated by trituration 15 times $(15 \times)$ followed by incubation $25 \mathrm{~min}$ at $37^{\circ} \mathrm{C}$ in a humidified incubator holding $5 \% \mathrm{CO}_{2}$. Tissue material was vortexed and trypsin $(1.25$ $\mathrm{mg} / \mathrm{mL}$, BioChrom, Berlin, Germany) and EDTA (0.01\%, Ethylenediaminetetraacetic acid, Sigma-Aldrich) added and the tissue was again triturated $15 \times$ and incubated rotating $20 \mathrm{~min}$ at $37^{\circ} \mathrm{C}, 5 \% \mathrm{CO}_{2}$. The tissue was vortexed and $50 \% \mathrm{vol} / \mathrm{vol}$ fetal calf serum (FCS, Gibco BRL, Life Technologies) was added. The cell suspension was passed through a rough mesh $(\varnothing 1 \mathrm{~mm})$, centrifuged at $7.4 \mathrm{~g}$ for $7 \mathrm{~min}$ and washed in HBSS, the washing procedure was repeated twice. The cell pellet was diluted to $2.5 \mathrm{~mL}$ in Neurobasal A (NBA) culture medium containing $10 \%$ FCS, $0.5 \mathrm{mM}$ L-glutamine, $50 \mathrm{U} / \mathrm{mL}$ penicillin $\mathrm{G}$ sodium and $50 \mu \mathrm{g} / \mathrm{mL}$ streptomycin sulphate (all from Gibco BRL, Life Technologies). Cell cultures were prepared by seeding $50 \mu \mathrm{l}$ of constantly mixed cell suspension into 8-well chambers (cat no 734-0402, BD Falcon, VWR, Göteborg, Sweden) prefilled with $450 \mu \mathrm{L}$ NBA and incubated in humidified incubator holding 5\% $\mathrm{CO}_{2}$. From each rat six 8-wells chambers (each well 69 $\mathrm{mm}^{2}$ ) were prepared; cell cultures were never prepared 
by pooling cell suspensions from different rats. After 4 days in vitro (4 DIV), $400 \mu \mathrm{L}$ of medium was replaced with fresh medium and, depending on experimental set up, mast cells (see below) and/or pharmacological agents were added. The cultures were then grown for 2 days $(4+2 \mathrm{DIV})$ followed by fixation for 30 minutes in a mixture of $2 \%$ formaldehyde and $0.2 \%$ picric acid (Stefanini's fixative) in $0.1 \mathrm{M}$ phosphate-buffer, $\mathrm{pH} 7.2$, rinsing twice in Tyrode's solution containing 10\% sucrose. In order to enhance antibody penetration, the cultures were frozen in $-20^{\circ} \mathrm{C}$ for at least $1 \mathrm{~h}$ before being processed for immunocytochemistry.

Evaluation was by neuronal cell counting. Parallel controls were cultured in NBA (supplemented as described above).

\section{Isolation of mast cells}

Adult female rats (Sprague-Dawley, 250-300 g, $\mathrm{n}=16$ ) were killed by cervical dislocation. Mast cells were obtained by peritoneal saline washings using procedures previously described [21]. In brief, peritoneal lavage was performed by injecting $10 \mathrm{~mL}$ saline containing heparin ( $5 \mathrm{U} / \mathrm{mL}$ ) into the peritoneal cavity followed by abdominal massage for $4 \mathrm{~min}$. The mast cell rich fluid (approximately $7 \mathrm{~mL}$ ) was removed and centrifuged at $15 \mathrm{~g}$ for $2 \mathrm{~min}$ at room temperature. Precipitated cells were resuspended in $1 \mathrm{~mL}$ NBA.

\section{Co-culturing myenteric neurons and mast cells}

To 4 DIV cultures of myenteric neurons $50 \mu \mathrm{L}(=18$ $988 \pm 1046$ mast cells, mean \pm SEM; see section "histochemistry" for details) of mast cell suspension was added. To test if GLP1, GLP2 or VIP inhibited mast cell-induced neuronal cell death the peptides $\left(10^{-9}-10^{-6}\right.$ $\mathrm{M})$ were added to the neuron-mast cell co-cultures, in the presence or absence of receptor antagonist.

At the end of experimentation, referred to as 4 (neuronal pre-culture period) +2 (co-culture period) $\mathrm{D} I V$ the cultures were fixed, rinsed (as described above) and frozen until being processed for immunocytochemistry. Evaluation was by neuronal cell counting after $4+2$ DIV. Parallel controls were cultured in NBA (supplemented as described above) with or without addition of mast cell and without peptides or receptor antagonists.

\section{Pharmacological agents}

To test if the presence of GLP1 (human GLP1(1-36) amide, PolyPeptide Laboratories A/S, Hillerød, Denmark), GLP2 (human GLP2(1-34), PolyPeptide Laboratories A/S) or VIP (rat VIP, Sigma-Aldrich) affected neuronal survival, the peptides were added separately $\left(10^{-11}-10^{-6} \mathrm{M}\right)$ to $4 \mathrm{DIV}$ cultures or co-cultures.

Possible inhibitory effects of GLP1 receptor antagonist exendin(9-39)amide (10 ${ }^{-7} \mathrm{M}$; Bachem) or VIP receptor antagonist hybVIP $\left(10^{-9} \mathrm{M}\right.$; hybrid neurotensin 6-11 and VIP 7-28, Bachem, St. Helens, UK) on GLP1-, GLP2-, or VIP- induced neuroprotection were tested by addition of the receptor antagonist simultaneously with the peptide studied. All substances were dissolved in sterile water.

\section{Histochemistry}

In order to estimate the number of mast cells seeded in each well, $50 \mu \mathrm{L}$ of the mast cell suspension was placed on a glass slide. Two such slides were performed from each rat. The slides were dried $\left(30 \mathrm{~min}\right.$ in $\left.37^{\circ} \mathrm{C}\right)$, fixed and rinsed as described above. To detect mast cells the slides were stained 10 min with $0.1 \%$ toluidine blue (CI 52 040). Mast cells become deep purple due to metachromasia. The number of mast cells per slide was estimated by computerized morphometry [21]. The total number of mast cells seeded (in $50 \mu \mathrm{L}$ mast cell suspension) was found to be $18988 \pm 1046$ mast cells (mean \pm SEM; $n=4$ ).

\section{Immunocytochemistry}

As general neuronal markers antibodies against $\mathrm{HuC}$ / $\mathrm{HuD}$ (a mouse monoclonal anti-human neuronal protein; code no A-21271; Molecular Probes, Eugene, OR, USA; dilution 1:400; [22]) or human protein gene product 9.5 (raised in rabbit, code no PGP9.5; Ultraclone, Isle of Wight, UK; dilution 1:1600; [21]) were used. In terms of number of nerve cell bodies visualized in vitro the $\mathrm{HuC} / \mathrm{HuD}$ and the PGP 9.5 antibodies gave identical results, as previously described [23]. Mast cells were detected by antibodies raised in rabbits against histamine coupled to human serum albumin using carbodiimide (code no 8432, Euro-Diagnostica AB, Malmö, Sweden; dilution 1:300; [24]).

Immunolabeling was done by incubation of the slides with primary antibodies in a moist chamber over night at $4^{\circ} \mathrm{C}$. For visualization, the slides were exposed to fluorescein isothiocyanate (FITC)- or Texas Red-conjugated goat anti-rabbit IgG antiserum (Jackson Immunoresearch Laboratories, West Grove, PA, USA; dilution 1:100) or FITC conjugated goat anti-mouse IgG antiserum (Jackson Immunoresearch Laboratories; dilution 1:100) for $1 \mathrm{~h}$, mounted in phosphate buffer:glycerol 1:1 and analyzed using a fluorescence microscope with appropriate filter settings. Since synthetic antigens for testing the specificities of the $\mathrm{HuC} / \mathrm{HuD}$ and PGP9.5 are not commercially available, omission of primary antibodies was used as control. In order to assess the specificity of the histamine antiserum $10 \mu \mathrm{M}$ histamine was incubated with the antibodies (dilution 1:300) over night before being exposed to the slides. Controls did not exhibit any immunostaining.

\section{Cell counting and statistical analysis}

Neuronal survival was calculated by counting the numbers of surviving neurons in the entire culture chamber 
after exposure to mast cells and/or pharmacological agents and expressed in percentage of the control run in parallel.

Statistical differences were determined using one-way analysis of variance test (ANOVA) followed by Dunnett's multiple comparison test (all comparisons against control column). Statistical analysis was performed using GraphPad Prism 5 (GraphPad Software Inc., San Diego, CA, USA)

\section{Results}

Myenteric neurons in culture and in co-culture with mast cells

Neurons cultured for $4+2$ days stained well with both $\mathrm{HuC} / \mathrm{HuD}$ and PGP9.5 and were uniformly dispersed throughout the culture wells. Neurons with rich networks of arborizing fibers were displayed after staining with PGP 9.5 antibodies (Figure $1 \mathrm{~A}$ ), while $\mathrm{HuC} / \mathrm{HuD}$ antibodies revealed nerve cell bodies only. The number of neurons was $4.9 \pm 0.4$ neurons $/ \mathrm{mm}^{2}(\mathrm{n}=24)$, as established on parallel controls.

Addition of mast cells to pre-cultured (4 DIV) myenteric neurons resulted in a disintegrated nerve fibre network and a markedly enhanced loss of nerve cell bodies (Figure 1B). After 2 days in co-culture $(4+2 \mathrm{DIV})$ the numbers of myenteric neurons were reduced to $2.4 \pm$ 0.2 neurons $/ \mathrm{mm}^{2}(\mathrm{n}=24), p<0.01$ as compared to neurons grown in parallel without the addition of mast cells.

Within the co-cultures mast cells dispersed uniformly, survived well and adhered to the bottom of the culture chambers. When stained with histamine antibodies or toluidine blue the mast cells were found to contain numerous granules within the cytoplasm (Figure 1C). Cultured mast cells often showed signs of degranulation and some exhibited piece meal degranulation (Figure 1D). Mast cells and neurons were occasionally seen in close proximity (Figures $1 \mathrm{E}$ and $1 \mathrm{~F}$ ).

\section{Survival of neurons after GLP1, GLP2 or VIP treatment}

Myenteric neurons pre-cultured for 4 days, followed by exposure to GLP1, GLP2 or VIP in different concentrations $\left(10^{-11}-10^{-6} \mathrm{M}\right)$ for 2 days $(4+2 \mathrm{DIV})$, showed a markedly increased neuronal survival, compared to untreated controls run in parallel. The increase was concentration-dependent for all three peptides. $\mathrm{EC}_{50}(\mathrm{M})$ values were $3 \times 10^{-11}$ for GLP1, $3.5 \times 10^{-10}$ for GLP2 and $4 \times 10^{-11}$ for VIP. Emax (\%; maximal neuronal survival as a percentage of control) values were $178.5 \pm 14.0$ for GLP1, $150.8 \pm 6.0$ for GLP2 and 150.4 \pm 8.4 for VIP.

Peptide receptor selectivity was tested in experiments using receptor antagonists for either GLP1 $\left(10^{-7} \mathrm{M}\right.$, exendin(9-39)amide) or VIP $\left(10^{-9} \mathrm{M}\right.$, hybVIP) receptors added simultaneously with the different peptides. In these experiments both the GLP1- and the VIP- receptor antagonists inhibited GLP1-induced increases in neuronal survival. GLP2-induced survival was unaffected by the addition of any of the two antagonists. VIPinduced survival was unaffected by the addition of exendin(9-39)amide but markedly attenuated by the addition of hybVIP. The results are summarized in Figure 2.

\section{Survival of neurons co-cultured with mast cells in the presence of GLP1, GLP2 or VIP}

Presence of GLP1, GLP2 or VIP $\left(10^{-9}-10^{-6} \mathrm{M}\right)$ within the co-cultures of myenteric neurons and mast cells significantly and concentration-dependently enhanced neuronal survival. At the highest concentration $\left(10^{-6} \mathrm{M}\right)$ all three peptides were able to completely reverse mast cell-induced neuronal cell death, as compared to neurons cultured in parallel in the absence of mast cells. Simultaneous presence of exendin $(9-39)$ amide $\left(10^{-7} \mathrm{M}\right)$ counteracted the effects of GLP1 while GLP2- or VIPinduced enhanced neuronal survival was unaffected. Addition of hybVIP $\left(10^{-9} \mathrm{M}\right)$ to the co-cultures hampered both GLP1- and VIP-induced neuroprotection. Results are summarized in Figure 3.

\section{Discussion}

\section{GLP1, GLP2 and VIP promote neuronal survival}

Our studies show that GLP1, GLP2 and VIP all were able to enhance survival of myenteric neurons in culture. Further all three peptides counteracted mast cellinduced neuronal cell death. Neuroprotection induced by GLP1 was reversed by either the addition of the GLP1 receptor antagonist, or the VIP receptor antagonist. GLP2-induced neuroprotection was unaffected by both the receptor antagonists, and VIP-induced neuroprotection was attenuated only by the VIP receptor antagonist. Taken together these results indicate that GLP1, GLP2 and VIP receptors are operating to promote neuronal survival in the ENS. GLP1 receptors are suggested to be localized on VIP-expressing myenteric neurons and to release VIP on activation, or act on a parallel pathway which converges with VIP-signaling to a common final mechanism. This is supported by the fact that GLP1-induced neuroprotective responses were blocked by the addition of the GLP1 receptor blocker exendin(9-39)amide, as well as by VIP receptor antagonist. VIP and GLP2 receptors are suggested to evoke direct protective effects on myenteric neurons upon activation.

The peptide concentrations studied verified the EC50 values to be clearly within the in vivo plasma concentration range in both man and rat as shown for GLP1 $[25,26]$, GLP2 $[25,27]$ and VIP $[28,29]$. 

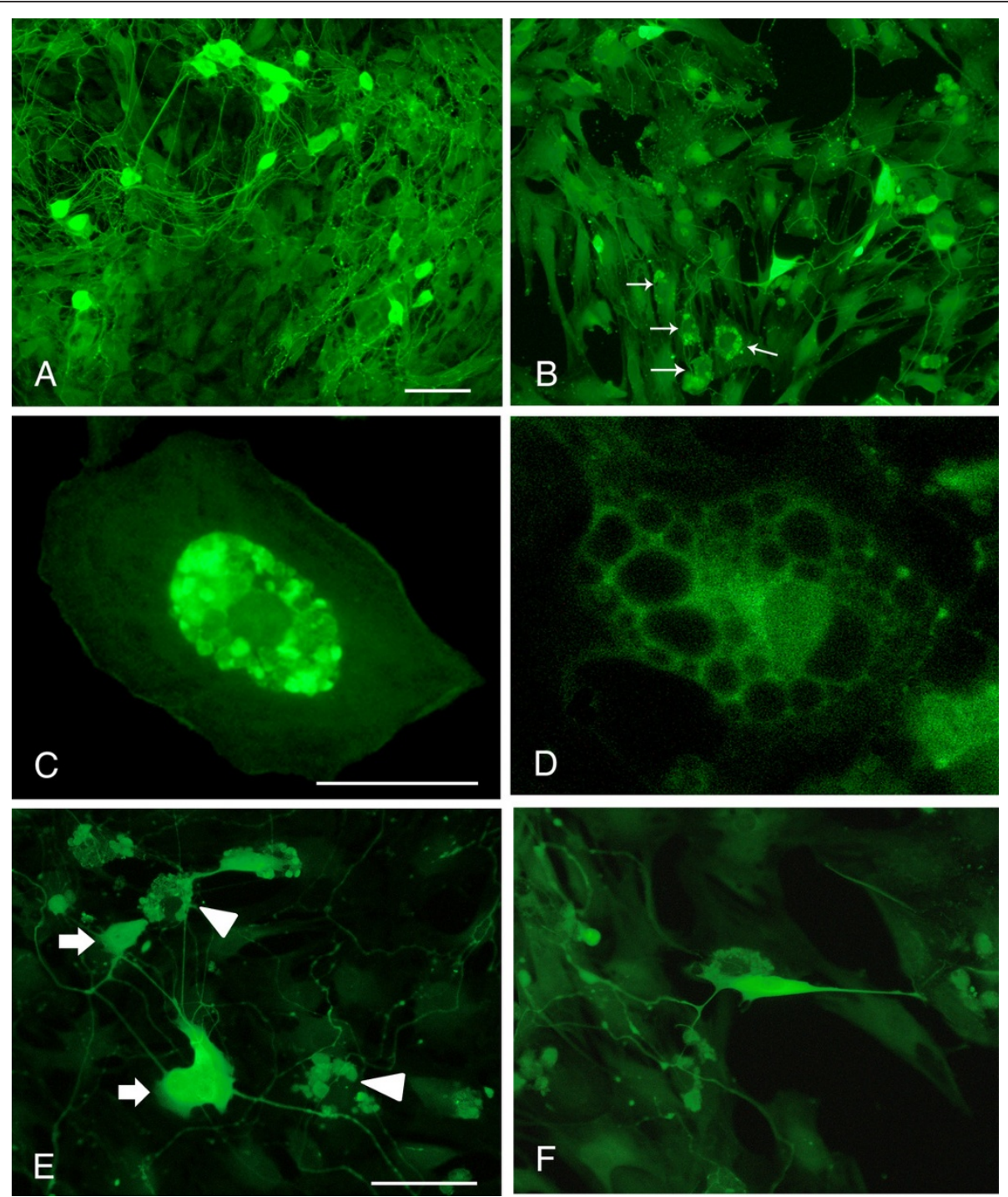

Figure $1 \mathrm{Immunocytochemical} \mathrm{staining} \mathrm{of} \mathrm{myenteric} \mathrm{neurons} \mathrm{cultured} \mathrm{in} \mathrm{absence} \mathrm{(A)} \mathrm{or} \mathrm{presence} \mathrm{(B-F)} \mathrm{of} \mathrm{peritoneal} \mathrm{mast} \mathrm{cells.} \mathrm{A}$ Neurons grown for 6 days and stained with PGP9.5. The cultured neurons survive well; they group into ganglion-like structures and grow a prominent arborizing network of nerve terminals. B. Neurons co-cultured with mast cells (arrows) stained with antibodies against PGP9.5 and histamine, respectively. In the neuronal cultures to which mast cells have been added the number of neurons markedly decreases and the terminal network is disintegrated. C and D. show mast cells grown in co-culture and stained with histamine antibodies. The mast cells are well settled within the cultures and they contain a high number of cytoplasmic granules. C. illustrates a cultured mast cell with numerous granules in the central, perinuclear, portion of the cell. D. shows a mast cell exhibiting piece meal degranulation. E and F. illustrate the morphological relationship of cultured neurons and mast cells. E. shows mast cells (arrowheads) in close contact with nerve terminals from nearby myenteric neurons (arrows). F. a mast cell and a nerve cell body in close proximity. In order to perceive the morphological arrangement of mast cells and neurons both PGP9.5- and histamine- immunoreactive cells are visualised by FITC conjugated antibodies. Neurons and mast cells are distinguished by their morphological characteristics. Bar in A $100 \mu \mathrm{m}$ represents also B, bar in C $40 \mu \mathrm{m}$ represents also D, bar in E $50 \mu \mathrm{m}$ represents also $\mathrm{F}$.

\section{VIP receptors}

The finding that VIP promotes neuronal survival of myenteric neurons in vitro is well in line with several previous observations $[16,17,19,20]$. Also the finding that the presence of VIP rescues myenteric neurons from mast cell-induced death is supported by previous findings [21]. VIP-mediated neuroprotective effects are in addition corroborated by several other studies performed in neurons belonging to the central nervous system [reviewed in [18]]. The receptor(s) by which VIP mediates neuroprotection is, however, enigmatic. Cloning of receptors for the VIP superfamily of peptides has revealed three distinct receptors activated by VIP; $\mathrm{VPAC}_{1}, \mathrm{VPAC}_{2}$ and $\mathrm{PAC}_{1}$ receptors [30]. All three are 


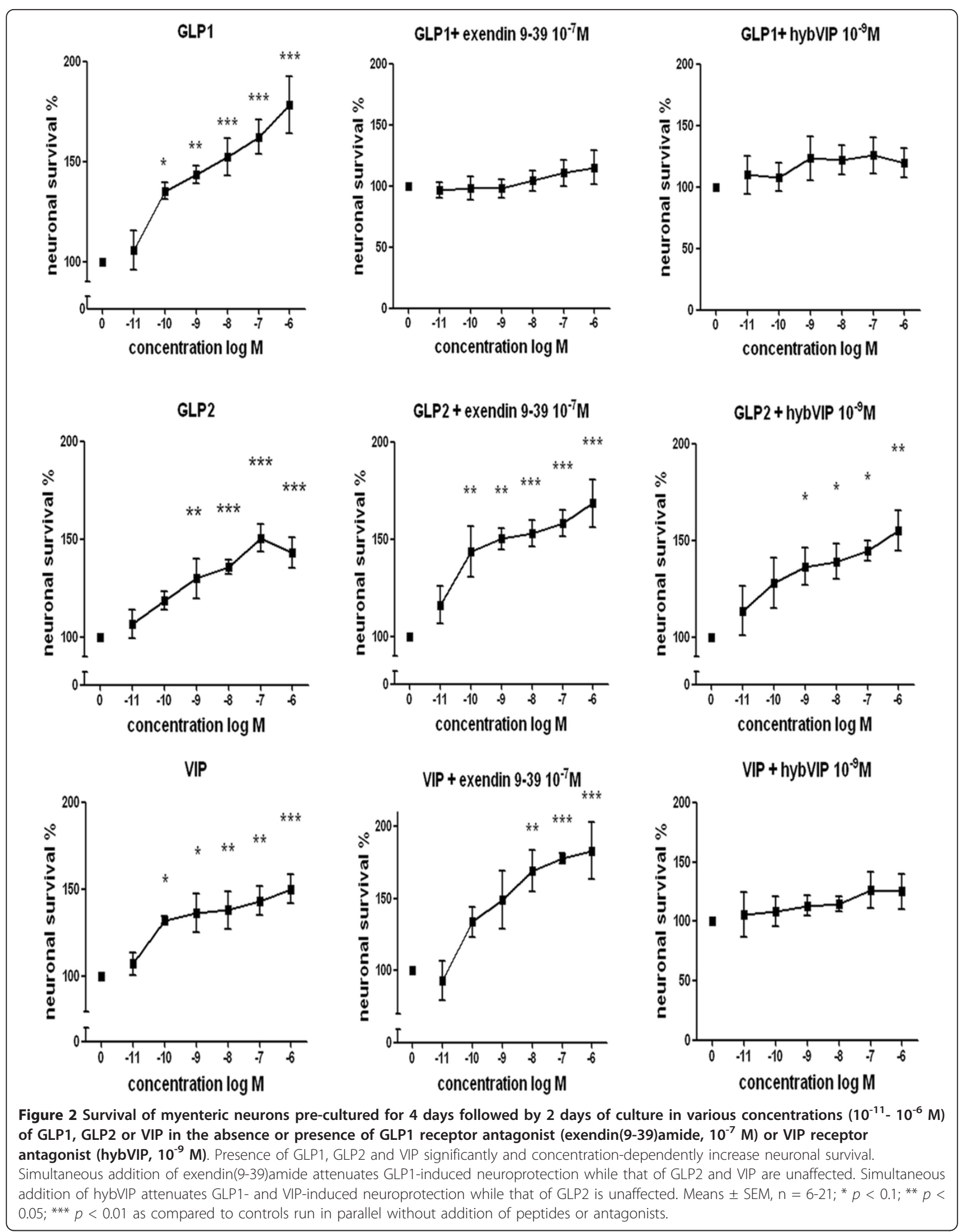




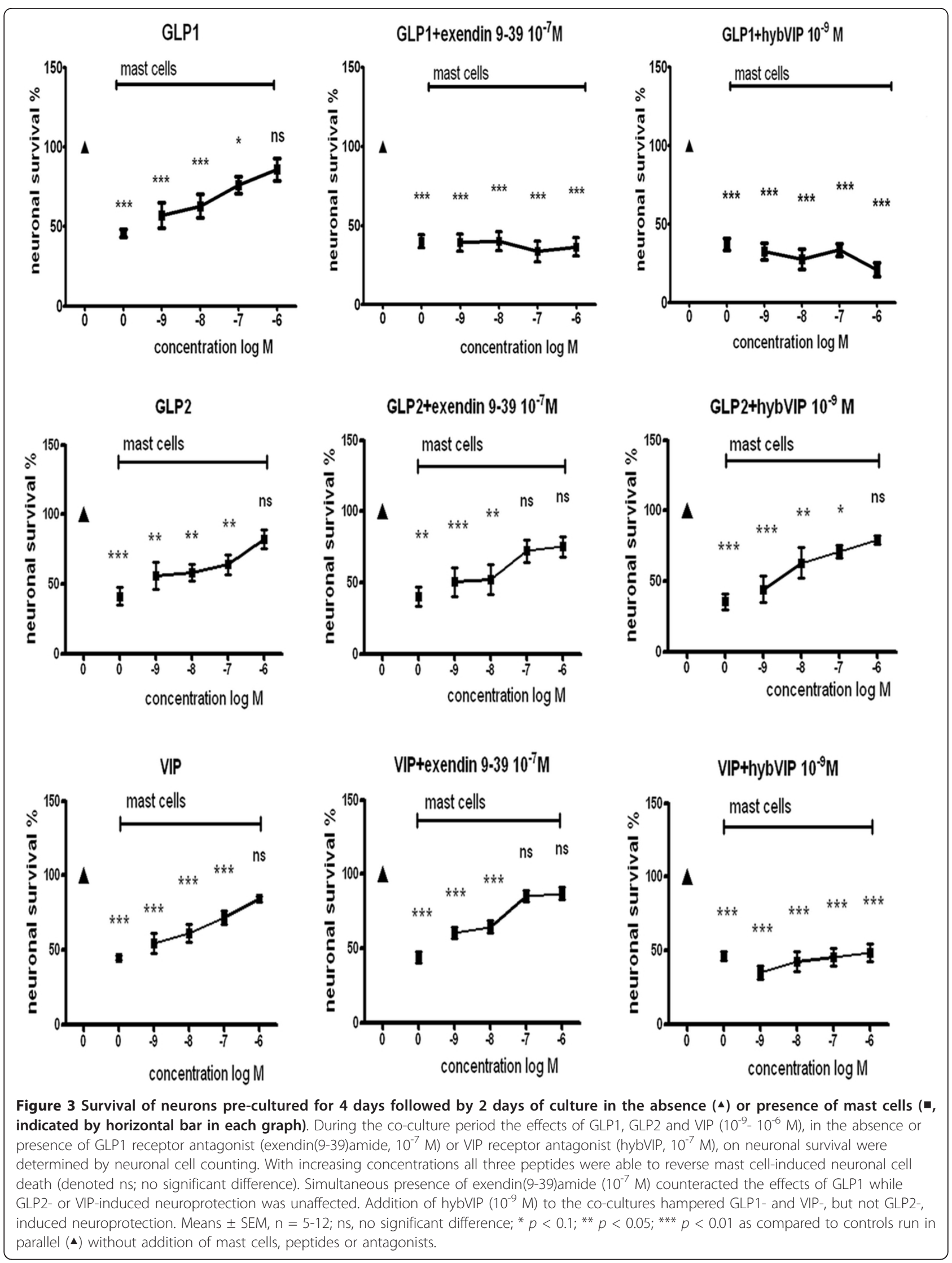


in addition high affinity receptors for pituitary adenylate cyclase-activating peptide (PACAP). Therefore the report that, in contrast to VIP, presence of PACAP does not elicit any neuroprotective effect on cultured rat myenteric neurons [19] led to the suggestion of "VIP specific" receptors. In the present study we have used a commercially available competitive antagonist of VIPbinding. The antagonist, a chimeric peptide consisting of neurotensin (6-11) and VIP (7-28), was found to antagonize the "VIP specific" receptor mediated neuroprotective effect on cultured rat myenteric neurons. Thus, this antagonist is suggested to have a broad spectrum resembling ( $\mathrm{N}$-stearyl, norleucine17)VIPhybrid which recognizes both $\mathrm{VPAC}_{1}$ and $\mathrm{VPAC}_{2}$ receptors as well as $\mathrm{PAC}_{1}$ receptors [31].

\section{GLP1 receptors}

GLP1 receptor stimulation is widely used clinically to improve glucose homeostasis in patients with type 2 diabetes $[6,32]$ but has also been recognized to mediate neuroprotection and neurotrophic effects. GLP1 was first described to protect central neurons against excitotoxicity [33,34] but later also to have neuroprotective properties in neurodegenerative diseases like Alzheimer's and Parkinson's diseases [9]. Protective effects of GLP1 on peripheral neurons have so far only been described in sensory neurons $[10,11]$.

A single GLP1 receptor, similar in rodents and man, has been cloned [35]. It is a 7-transmembrane G-protein coupled receptor with structural similarities to the GLP2 receptor. GLP1 receptors are widely expressed throughout the body in e.g. digestive tract, kidney and in peripheral as well as central neurons [35]. Myenteric neurons in both small and large intestine of mice express GLP1 receptors [36]. In the present study we suggest, based on the ability of both hybVIP and exendin(9-39)amide to antagonize the GLP1-induced neuroprotective effects, that GLP1 binds to GLP1 receptors localized on VIP-expressing myenteric neurons, thereby causing release of VIP. The thus released VIP is responsible for GLP1-induced neuroprotection of cultured myenteric neurons.

The finding that GLP1, by way of VIP release, executes neuroprotection on myenteric neurons highlights the possibility of additional beneficial effects activated by the use of GLP1 receptor stimulation to achieve better metabolic control in type 2 diabetes clinically. Such treatment would provide neuroprotection of the ENS which may be speculated to attenuate diabetic neuropathy in the GI tract. In this context it is of interest also to note the fact that enteric myenteric neurons issue intestinofugal projections to pancreatic ganglia [37] and that VIP stimulates insulin release from pancreatic islets [38]. GLP1 stimulation of VIP-expressing enteric neurons may thus be yet another mechanism by which GLP1 analogue-based therapies execute beneficial effects on insulin release and glucose homeostasis.

\section{GLP2 receptors}

Within the GI tract GLP2 has significant intestinotrophic effects involving diverse cellular organisations despite the finding that GLP2 receptors are mainly localized on enteric neurons, endocrine cells and subepithelial myofibroblasts [39]. The restricted GLP2 receptor distribution has led to the proposal that the multitude of GLP2-induced effects is mediated by indirect mediators and diverse signaling pathways [40]. One such mediator is VIP. In mouse, GLP2-induced gastric relaxation is executed by prejunctional neuronal VIP release [41]. GLP2 has further been found to attenuate inflammation-induced intestinal damage and levels of proinflammatory cytokines in animal models of intestinal inflammation via release of VIP [14,15]. GLP2 further prevents loss of submucous neurons in inflamed bowel and increases the proportion of VIP-expressing neurons within submucous ganglia in both inflamed and noninflamed bowel [15]. The neuroprotective effect of GLP2 demonstrated in vivo on submucous neurons is well in agreement with our present in vitro findings indicating significantly improved neuronal survival and a rescue from mast cell-induced neuronal cell death of cultured myenteric neurons when exposed to GLP2. The data presented here suggests that GLP2-induced neuroprotection of myenteric neurons is mediated by direct stimulation of neuronal GLP2 receptors and not executed by VIP release or by activation of GLP1 receptors. This since the GLP2-induced increase in neuronal survival was unaffected by the presence of hybVIP and exendin (9-39)amide. However, we cannot definitely exclude indirect mediators derived from e.g. enteric glia. Such cells are unavoidably present within the primary cultures of myenteric neurons as well as within the co-cultures consisting of mast cells and neurons. A similar dilemma concerning direct $v s$ indirect GLP2 effects is faced by the in vivo studies on experimental colitis [15]. In these studies the GLP2 neuroprotective effect on submucous neurons was suggested to be either direct or due to the general anti-inflammatory effects caused by systemic GLP2 treatment. In addition to enteric neurons GLP2mediated neuroprotective effects have also been demonstrated in central, i.e. hippocampal, neurons $[42,43]$ signifying that GLP2 receptor stimulation may promote survival in different types of neurons.

\section{GLP1, GLP2 and VIP rescue neurons from mast cell- induced cell death}

Although mast cells have been ascribed a role in the metabolic syndrome and type 2 diabetes 
pathophysiology [44] the main reason for testing neuronal survival in co-cultures of myenteric neurons and mast cells was to test VIP, GLP1 and GLP2 effects in an in vitro setting in which neuronal cell death was actively enhanced. Mast cells have been shown to induce death of myenteric neurons in vitro by way of degranulation and also by release of mediators not stored within granula. Prostaglandin $\mathrm{D}_{2}$ and interleukin-6, known mast cells mediators, induce death of myenteric neurons in vitro as do proteinase-activated receptor $_{2}$ activation [21]. The mechanisms by which GLP1, GLP2 and VIP rescue myenteric neurons from mast cell-induced cell death needs further examination but is probably executed by direct activation of neuronal receptors, as in neuronal cultures without the addition of mast cells. The effects of the peptides are mediated via activation of separate receptors in both experimental models used in the present study. It may be speculated that GLP1, GLP2 and VIP, in the co-cultures, have direct e.g. stabilizing effects on mast cells but present data does not substantiate such speculations. Whether mast cells express GLP1 or GLP2 receptors is at present unknown. Human mast cells in culture express VIP receptors of $\mathrm{VPAC}_{2}$ type which, upon activation, cause mast cell degranulation [45]. Given that this applies also to cultured rat mast cells then VIP exposure would be suspected to cause an even more severe neuronal cell loss within the neuronmast cell co-cultures. In this context it is noteworthy that brain mast cells, upon VIP activation, are suggested to participate in central neuronal protection by adopting a nondegranulating phenotype [46]. Thus the detailed mechanisms behind the VIP-induced neuroprotection, as well as that induced by the GLPs, are still unresolved.

\section{Conclusions}

The neuroprotective effects of the GLPs and VIP on myenteric neurons are powerful and worthy of further exploration in view of the large number of patients facing enteric neuropathy. Neuroprotection of the ENS is in the present work recognized as yet another positive effect resulting from incretin-based therapies.

\footnotetext{
Abbreviations

ANOVA: analysis of variance; D/V: days in vitro; EDTA:

ethylenediaminetetraacetic acid; ENS: enteric nervous system; FCS: fetal calf serum; FITC: fluorescein isothiocyanate; Gl: gastrointestinal; GLP1: glucagon like peptide 1; GLP2: glucagon like peptide 2; HBSS: Hank's balanced salt solution; HuC/HuD: human neuronal proteins HuC and HuD; hybVIP: hybrid neurotensin 6-11 and vasoactive intestinal peptide 7-28; IBD: inflammatory bowel disease; NBA: culture medium neurobasal A; NO: nitric oxide; NOS: nitric oxide synthase; PACAP: pituitary adenylate cyclase-activating peptide; $P A C_{1}: V P A C_{1}$ and $V P A C_{2}$ receptors: receptors for vasoactive intestinal peptide and pituitary adenylate cyclase activating peptide; PGP9.5: protein gene product 9.5; TUNEL: terminal deoxynucleotidyl transferase dUTP nick end labelling; VIP: vasoactive intestinal peptide.
}

\section{Acknowledgements}

Grant support: Swedish Medical Research Council (projects no K2010-79X 21385-01-2 and K2008-55X-13406-09-3), Royal Physiographic Society, Bengt Ihre Foundation and Lund Medical Faculty. We thank Anna Themner-Persson for valuable technical assistance.

\section{Author details}

'Department of Experimental Medical Science, BMC B11, Lund University, SE22184 Lund, Sweden. ${ }^{2}$ Department of Medical Sciences, Uppsala University, SE-75185 Uppsala, Sweden.

\section{Authors' contributions}

UV, ES and EE performed the experimentation. EE and UV analyzed data and wrote the manuscript. PH provided GLP and participated in the writing of the manuscript. EE conceived and designed the study. All authors read and approved the final manuscript.

\section{Competing interests}

The authors declare that they have no competing interests.

Received: 16 November 2011 Accepted: 1 April 2012

Published: 1 April 2012

\section{References}

1. Hammar J, Howell S, Bytzer P, Horowitz M, Talley NJ: Symptom clustering in subjects with and without diabetes mellitus: A population-based study of 15000 Australian adults. Am J Gastroenterol 2003, 98:391-398.

2. Chandrasekharan B, Srinivasan S: Diabetes and the enteric nervous system. Neurogastroenterol Motil 2007, 19:951-960.

3. Guo C, Quobatari A, Shangguan Y, Hong S, Wiley JW: Diabetic autonomic neuropathy: evidence for apoptosis in situ in the rat. Neurogastroenterol Motil 2004, 16:335-345.

4. Shotton HR, Broadbent S, Lincoln J: Prevention and partial reversal of diabetes-induced changes in enteric nerves of rat ileum by combined treatment with alpha-lipoic acid and evening primrose oil. Autonom Neurosci 2004, 111:57-65

5. Voukali E, Shotton HR, Lincoln J: Selective responses of myenteric neurons to oxidative stress and disbetic stimuli. Neurogastroenterol Motil 2011, 23:964-e411.

6. Brubaker PL: Minireview: Update on incretin biology: Focus on glucagonlike peptide-1. Endocrinology 2010, 151:1984-1989.

7. Li Y, Hansotia T, Yusta B, Ris F, Halban PA, Drucker DJ: Glucagon-like peptide-1 receptor signaling modulates beta cell apoptosis. J Biol Chem 2003, 278:471-478.

8. Li Y, Perry T, Kindy MS, Harvey BK, Tweedie D, Holloway HW, Powers K, Shen H, Egan JM, Sambamurti K, Brossi A, Lahiri DK, Mattson MP, Hoffer BJ, Wang Y, Greig NH: GLP-1 receptor stimulation preserves primary cortical and dopaminergic neurons in cellular and rodent models of stroke and Parkinsonism. Proc Natl Acad Sci USA 2009, 106:1285-1290.

9. Harkavyi A, Whitton PS: Glucagon-like peptide 1 receptor stimulation as a means of neuroprotection. Brit J Pharmacol 2010, 159:495-501.

10. Jin HY, Liu WJ, Park JH, Baek HS, Park TS: Effect of dipeptidyl peptidase-IV (DPP-IV) inhibitor (vildagliptin) on peripheral nerves in streptozotocininduced diabetic rats. Arch Med Res 2009, 40:536-544.

11. Perry T, Holloway HW, Weerasuriya A, Mouton PR, Duffy K, Mattison JA, Greig NH: Evidence of GLP-1-mediated neuroprotection in an animal model of pyridoxine-induced peripheral sensory neuropathy. Exp Neurol 2007, 203:293-301

12. Hellström PM, Hein J, Björnsson E, Kristensen J, Schambye H: Clinical trial: the glucagon-like peptide- 1 analogue ROSE-010 for management of acute pain in patients with irritable bowel syndrome: a randomized, placebo-controlled, double-blind study. Aliment Pharmacol Ther 2008, 29:198-206.

13. Estall JL, Drucker DJ: Glucagon-like peptide 2. Ann Rev Nutr 2006 26:391-411.

14. Sigalet DL, Wallace LE, Holst JJ, Martin GR, Kaji T, Tanaka H, Sharkey KA: Enteric neural pathways mediate the anti-inflammatory actions of glucagons-like peptide 2. Am J Physiol Gastrointest Liver Physiol 2007, 293 G211-221. 
15. Sigalet DL, Wallace L, De Heuval E, Sharkey KA: The effects of glucagonlike peptide 2 on enteric neurons in intestinal inflammation. Neurogastrenterol Motil 2010, 22:1318-1325.

16. Arciszewski MB, Ekblad E: Effects of vasoactive intestinal peptide and galanin on survival of cultured porcine myenteric neurons. Regulatory Peptides 2005, 125:185-192.

17. Arciszewski MB, Sand E, Ekblad E: Vasoactive intestinal peptide rescues cultured rat myenteric neurons from lipopolysaccharide induced cell death. Regulatory Peptides 2008, 146:218-223.

18. Brenneman DE: Neuroprotection: a comparative view of vasoactive intestinal peptide and pituitary adenylate cyclase-activating polypeptide. Peptides 2007, 28:1720-1726.

19. Sandgren K, Lin Z, Ekblad E: Differential effects of VIP and PACAP on survival of cultured adult rat myenteric neurons. Regulatory Peptides 2003, 111:211-217.

20. Sandgren K, Lin Z, Fex-Svenningsen $\AA$, Ekblad E: Vasoactive intestinal peptide and nitric oxide promote survival of adult rat myenteric neurones in culture. J Neurosci Res 2003, 72:595-602.

21. Sand E, Themner-Persson A, Ekblad E: Mast cells reduce survival of myenteric neurons in culture. Neuropharmacol 2009, 56:522-530.

22. Lin Z, Sandgren K, Ekblad E: Increased expression of vasoactive intestinal peptide in cultured myenteric neurons from rat small intestine. Autonom Neurosci 2003, 107:9-19.

23. Sand E, Themner-Persson A, Ekblad E: Corticotropin releasing factor Distribution in rat intestine and role in neuroprotection. Regulatory Peptides 2011, 166:68-75.

24. Håkanson R, Böttcher G, Ekblad E, Panula P, Simonsson M, Dohlsten M, Hallberg T, Sundler F: Histamine in endocrine cells in the stomach: a survey of several species using a panel of histamine antibodies. Histochemistry 1986, 86:5-17.

25. Ørskov C, Holst Jj: Radio-immunoassays for glucagon-like peptides 1 and 2 (GLP-1 and GLP-2). Scand J Clin Lab Invest 1987, 47:165-74.

26. Bucinskaite V, Tolessa T, Pedersen J, Rydqvist B, Zerihun L, Holst JJ, Hellström PM: Receptor-mediated activation of gastric vagal afferents by glucagon-like peptides-1 in the rat. Neurogastroenterol Motil 2009, 21:978-e78.

27. Fischer KD, Dhanvantari S, Drucker DJ, Brubaker PL: Intestinal growth is associated with elevated levels of glucagon-like peptide 2 in diabetic rats. Am J Physiol 1997, 273:E815-820

28. Matsumura M, Saito S: Effect of bile salts on the plasma concentration of immunoreactive vasoactive intestinal polypeptide in man. Endocrinol Jpn 1989, 36:15-21.

29. Shimatsu A, Kato Y, Matsushita N, Katakami H, Yanaihara N, Imura H: Stimulation by serotonin of vasoactive intestinal polypeptide release into rat hypophysial portal blood. Endocrinology 1982, 111:338-340.

30. Harmar AJ, Arimura A, Gozes I, Journot L, Laburthe M, Pisenga JR, Rawlings SR, Robberecht P, Said SI, Sreedharan SP, Wank SA, Waschek JA: International union of pharmacology. XVIII. Nomenclature of receptors for vasoactive intestinal peptide and pituitary adenylate cyclaseactivating polypeptide. Pharmacol Rev 1998, 50:265-270.

31. Moody TW, Jensen RT, Fridkin M, Gozes I: (N-stearyl, norleucine17) VIPhybrid is a broad spectrum vasoactive intestinal peptide receptor antagonist. J Mol Neurosci 2002, 17:29-35.

32. Martin JH, Deacon CF, Gorell MD, Prins JB: Incretin-based therapies review of the physiology, pharmacology and emerging clinical experience. Internal Medicine Journal 2011, 41:299-307.

33. Perry T, Haughey NJ, Mattson MP, Egan JM, Greig NH: Protection and reversal of excitotoxic neuronal damage by glucagons-like peptide-1 and exendin-4. J Pharmacol Exp Ther 2002, 302:881-888.

34. During MJ, Cao L, Zuzga DS, Francis JS, Fitzsimons HL, Jiao X, Bland RJ, Klugmann M, Banks WA, Drucker DJ, Haile CN: Glucagon-like peptide-1 receptor is involved in learning and neuroprotection. Nature Medicine 2003, 9:1173-1179.

35. Baggio LL, Drucker DJ: Biology of incretins: GLP-1 and GIP. Gastroenterology 2007, 132:2131-2157.

36. Amato A, Cinci L, Rotondo A, Serio R, Faussone-Pellegrini MS, Vannucchi M, Mulè F: Peripheral motor action of glucagon-like peptide-1 through enteric neuronal receptors. Neurogastroenterol Motil 2010, 22:664-671.

37. Kirchgessner AL, Liu MT, Gershon MD: In situ identification and visualization of neurons that mediate enteric and enteropancreatic reflexes. J Comp Neurol 1996, 371:270-286.
38. Sörhede Winzell M, Ahrén B: G-protein-coupled receptors and islet function - Implications for treatment of type 2 diabetes. Pharmacol Ther 2007, 116:437-448

39. Guan X, Karpen HE, Stephens J, Bukowski JT, Niu S, Zhang G, Stoll B, Finegold MJ, Holst JJ, Hadsell D, Nichols BL, Burrin DG: GLP-2 receptor localizes to enteric neurons and endocrine cells expressing vasoactive peptides and mediates increased blood flow. Gastroenterology 2006, 130:150-164.

40. Rowland KJ, Brubaker PL: The "cryptic" mechanism of action of glucagonlike peptide-2. Am J Physiol Gastrintest Liver Physiol 2011, 301:G1-8.

41. Amato $A$, Baldassano $S$, Serio $R$, Mulè $F$ : Glucagon-like peptide-2 relaxes mouse stomach through vasoactive intestinal peptide release. Am J Physiol Gastrintest Liver Physiol 2009, 296:G678-684.

42. Lovshin JA, Huang Q, Seaberg R, Brubaker PL, Drucker DJ: Extrahypothalamic expression of the glucagon-like peptide-2 receptor is coupled to reduction of glutamate-induced cell death in cultured hippocampal cells. Endocrinology 2004, 145:3495-3506.

43. Shi X, Li X, Wang Y, Zhang K, Zhou F, Chan L, Li D, Guan X: Glucagon-like peptide-2-stimulated protein synthesis through the PI 3-kinasedependent Akt-mTOR signaling pathway. Am J Physiol Endocrinol Metab 2011, 300:E554-563.

44. Zhang J, Shi G-P: Mast cells and metabolic syndrome. Biochem Biophys Acta 2012, 1822:14-20.

45. Kulka M, Sheen CH, Tancowny BP, Grammer LC, Schleimer RP: Neuropeptides activate human mast cell degranulation and chemokine production. Immunology 2007, 123:398-410.

46. Korkmaz OT, Tunçel N, Tunçel M, Öncü EM, Sahintürk V, Celik M: Vasoactive intestinal peptide (VIP) treatment of parkinsonian rats increases thalamic gamma-aminobutyric acid (GABA) levels and alters the release of nerve growth factor (NGF) by mast cells. J Mol Neurosci 2010, 41:278-287.

\section{Pre-publication history}

The pre-publication history for this paper can be accessed here: http://www.biomedcentral.com/1471-230X/12/30/prepub

doi:10.1186/1471-230X-12-30

Cite this article as: Voss et al.: Glucagon-like peptides 1 and 2 and

vasoactive intestinal peptide are neuroprotective on cultured and mast cell co-cultured rat myenteric neurons. BMC Gastroenterology 2012 12:30.

\section{Submit your next manuscript to BioMed Central and take full advantage of:}

- Convenient online submission

- Thorough peer review

- No space constraints or color figure charges

- Immediate publication on acceptance

- Inclusion in PubMed, CAS, Scopus and Google Scholar

- Research which is freely available for redistribution

Submit your manuscript at www.biomedcentral.com/submit
C Biomed Central 